\title{
Healthy dietary habits in relation to social determinants and lifestyle factors
}

\author{
Lars Johansson $^{1}$, Dag S. Thelle ${ }^{2}$, Kari Solvoll ${ }^{3}$, Gunn-Elin Aa. Bjørneboe ${ }^{1}$ and Christian A. Drevon ${ }^{3}$ \\ ${ }^{1}$ National Nutrition Council, Box 8139 Dep, N-0033 Oslo, Norway \\ ${ }^{2}$ Centre for Epidemiologic Research, University of Oslo, Norway \\ ${ }^{3}$ Institute for Nutrition Research, University of Oslo, Norway
}

(Received 3 April 1997 - Revised 8 October 1998 - Accepted 13 October 1998)

\begin{abstract}
The aim of the present study was to evaluate the importance of social status and lifestyle for dietary habits, since these factors may influence life expectancy. We studied the association of four indicators for healthy dietary habits (fruits and vegetables, fibre, fat and Hegsted score) with sex, age, socio-economic status, education, physical leisure exercise, smoking and personal attention paid to keeping a healthy diet. Data were gathered with a self-administered quantitative food-frequency questionnaire distributed to a representative sample of Norwegian men and women aged 16-79 years in a national dietary survey, of whom 3144 subjects (63\%) responded. Age and female sex were positively associated with indicators for healthy dietary habits. By separate evaluation length of education, regular physical leisure exercise and degree of attention paid to keeping a healthy diet were positively associated with all four indicators for healthy dietary habits in both sexes. Socio-economic status, location of residence and smoking habits were associated with from one to three indicators for healthy dietary habits. In a multiple regression model, age, education and location of residence together explained from 1 to $9 \%$ of the variation $\left(R^{2}\right)$ in the four dietary indicators. Length of education was significantly associated with three of four dietary indicators both among men and women. By including the variable 'attention paid to keeping a healthy diet' in the model, $R^{2}$ increased to between 4 and $15 \%$ for the four dietary indicators. Length of education remained correlated to three dietary indicators among women, and one indicator among men, after adjusting for attention to healthy diet, age and location of residence. Residence in cities remained correlated to two indicators among men, but none among women, after adjusting for age, education and attention to healthy diet. In conclusion, education was associated with indicators of a healthy diet. Attention to healthy diet showed the strongest and most consistent association with all four indicators for healthy dietary habits in both sexes. This suggests that personal preferences may be just as important for having a healthy diet as social status determinants.
\end{abstract}

Diet: Social status: Lifestyle

Dietary factors such as total fat, saturated fatty acids and salt are associated with increased risk of cardiovascular diseases and cancer, whereas fibre, fruits and vegetables may decrease this risk (Department of Health and Human Services, 1988; World Health Organization, 1990; Ministry of Health and Social Affairs, 1992; World Cancer Research Fund/American Institute for Cancer Research, 1997). The prevalence of risk factors for cardiovascular diseases (Kaplan \& Keil, 1993; Thürmer, 1993) and the mortality from cancer and cardiovascular diseases (Kristofersen, 1986; Blaxter, 1987; Mackenbach et al. 1997) are inversely related to socio-economic status. Several studies have shown that groups with high socio-economic status practise more healthy behaviours than low-status groups (Aarø, 1986; Prättälä et al. 1994; Lynch et al. 1997), and that skewed distribution of health behaviour, including dietary habits, may explain differences in mortality and morbidity between social classes (Holme et al. 1980; Jacobsen \& Thelle, 1988; Marmot et al. 1991; Lynch et al. 1996). Socio-economic differences in food consumption have been found in many dietary surveys (Axelson, 1986; Hulshof et al. 1991; Smith \& Baghurst, 1992), however, differences in nutrient intake tend to be less apparent. For example, the British national dietary survey (Gregory et al. 1990), showed that vitamin and mineral intakes, but not fat intake, were related to socioeconomic status. A large Finnish survey (Roos et al. 1996) 
also showed that socio-economic differences in intake of fat and other macronutrients were small or non-existent; the only substantial differences were found for vitamin $\mathrm{C}$ and carotenoids. This is in contrast to the first FINMONICA survey in 1982 (Pietinen et al. 1988) which showed that bluecollar $v$. white-collar workers had higher intakes of saturated fatty acids and cholesterol. The Dutch national dietary survey (Hulshof et al. 1991), as well as a survey among randomly selected urban Australian adults (Smith \& Baghurst, 1992) showed that higher social status was generally associated with healthier dietary intake. However, these differences did not appear to be large enough to be a major explanatory variable for the variation in disease risk between groups.

Commonly-used indicators of socio-economic status in epidemiological surveys have been education, occupation and income (Liberatos et al. 1988; Winkleby et al. 1992; Kaplan \& Keil, 1993). The strongest and most consistent relationships between socio-economic status and risk factors have been found for education (Liberatos et al. 1988; Winkleby et al. 1992; Luoto et al. 1994), and it is also shown that education may be the most important social predictor for a healthy diet (Blaxter, 1990). Several studies suggest that nutritional knowledge and health-related attitudes may be more closely associated with dietary intake than traditional socio-economic characteristics (Hollis et al. 1986; Witte et al. 1991; Hulshof et al. 1992; Smith \& Owen, 1992). A number of models have been suggested to explain health behaviour, such as the knowledge-attitude-practice model; social learning theory and health locus of control; the health belief model; the theory of reasoned action; and Bandura's social cognitive theory reinforcements (Mæland \& Aarø, 1993). Efforts have been made to integrate elements from the different models, but we still do not have a holistic model that can explain health behaviour. Across the models, the most important regulatory factors for behaviour seem to be social norms, personal expectations and environmental reinforcements (Mæland \& Aarø, 1993).

The aim of the present study was to evaluate the importance of social status and lifestyle in determining dietary habits. We examined the relationship between indicators for a healthy diet, and education, socio-economic status, income, location of residence, and some lifestyle variables in a nationwide dietary survey. In addition to classical lifestyle variables, we asked about the degree of attention paid to keeping a healthy diet. This attitude variable was used as an indicator of the participants' personal preferences. We wanted to examine if this attitude had an independent association with the quality of dietary habits.

The main hypotheses to be tested in this report were: (a) healthy dietary habits differ between low and high social status groups, evaluated by length of education and socio-economic status; (b) indicators for healthy lifestyle, such as regular leisure time physical exercise and non-smoking, are associated with healthy dietary habits; (c) the degree of attention paid to keeping a healthy diet is more strongly associated with healthy dietary habits than length of education.

\section{Experimental}

\section{Sample}

The dietary survey was coordinated with Statistics
Norway's Omnibus Surveys and undertaken during June, September and November 1993, and March 1994. A nationwide, representative random sample of 2500 Norwegians aged 16-79 years was drawn for each Omnibus Survey. A random half of each of these samples was invited to participate in the dietary survey, approximately 1250 subjects in each period (Central Bureau of Statistics, 1977; Statistics Norway, 1993). A quantitative food-frequency questionnaire was mailed to the subjects together with information letters about the Omnibus and the dietary survey, later called NORKOST. After 1-3 weeks the questionnaire was collected by personnel from Statistics Norway. Non-responders got one reminder by mail after 4 weeks. For each round of the Omnibus Survey the Norwegian Data Inspectorate was notified according to standard procedures.

Of the original sample for the survey, twenty-eight died or emigrated and were therefore excluded from the sample. Of the remaining 4980 subjects 3227 returned their questionnaire. In total eighty-three questionnaires were rejected, and $3144(63 \%)$ were used for further analysis. The distribution of subjects in different groups of socio-economic status, location of residence and length of education, were similar in NORKOST compared with the general population (Statistics Norway, 1995). There were only small differences between responders and the total random sample regarding age, sex, geographical distribution and educational level (Johansson et al. 1997a). However, the response rate was significantly lower in the age group 70-79 years (46\%), among subjects living in cities $(59 \%)$ and for subjects with low education $(52 \%)$, as compared with the other subjects. A detailed description of the subjects, the questionnaire and the calculation of nutrients is given elsewhere (Johansson et al. 1997a,b).

\section{Questionnaire}

The self-administered, optical mark readable quantitative food-frequency questionnaire was designed to cover the whole diet and included about 180 food items. The frequency of consumption was given per day, per week or per month depending on the food item. The portion sizes were units such as slices, glasses, cups, pieces, decilitres and spoons. The portion sizes of the different food items were converted to weights on the basis of standard portions estimated from previous Norwegian dietary studies (Blaker \& Aarsland, 1989). We also included questions about weight, height, physical activity, smoking habits, meal frequency and attitudes towards diet and body weight. Statistics Norway provided information about the subjects' level of education and several other demographic and geographical variables from their registers. The intake of nutrients from cod-liver oil, and vitamin and mineral supplements was not included in the calculations presented in the present paper. The following variables were included in our analysis.

Indicators for dietary habits. (a) Fruits and vegetables (fresh fruits and berries, orange juice and fresh, frozen and canned vegetables, excluding potatoes) and (b) fibre, both presented as $\mathrm{g} / 10 \mathrm{MJ}$; (c) fat as a percentage of total energy intake $(\mathrm{E} \%)$; (d) Hegsted score $(\mathrm{mg} / \mathrm{dl})$ providing an 
estimate of the impact of dietary lipids on serum cholesterol (Hegsted et al. 1993). This was determined according to Hegsted's equation (serum cholesterol $(\mathrm{mg} / \mathrm{dl})=2 \cdot 1$ saturated fatty acids $(\mathrm{E} \%)-1 \cdot 16$ polyunsaturated fatty acids $(\mathrm{E} \%)+0.067$ cholesterol $(\mathrm{mg} / 4184 \mathrm{~kJ}))$.

Socio-demographic variables. Education was classified as short $(<13$ years in school, upper secondary school or lower) or long ( $\geq 13$ years in school, at least at college or university level) (Central Bureau of Statistics, 1989). Length of education (5-20 years) was also used as a continuous variable in the regression model. The participants were categorized into twelve socio-economic status groups according to official standards for classification (Central Bureau of Statistics, 1984). This classification uses a combination of several variables, such as having paid work or not; type of occupation; length and type of education; and authority. In the present analysis two aggregates of socio-economic status were used; blue-collar workers (unskilled and skilled workers, and lower level salaried employees) and white-collar workers (mean and higher level salaried employees). Income per year was split into tertiles separately for each sex. Location of residence was classified as rural ( $<200$ inhabitants), urban (200-99999 inhabitants) or cities ( $\geq 100000$ inhabitants), based on Norwegian standards (Statistics Norway, 1994).

Lifestyle variables. Attention to healthy diet was categorized as very low, low, medium, high or very high (score $0-4$ ) by the question: How much attention do you pay to keeping a healthy diet? Smoking habits were classified as non-smoking, smoking $\leq 10$ or $\geq 11$ cigarettes or pipes daily. Frequency of exercise was classified as $<1$, $1-3$ or $\geq 4$ times/week by the question: How often do you have physical exercise for at least 20 min (walking, jogging, bicycling, swimming)?

\section{Statistics}

Data for men and women were analysed separately by the Statistical Package for the Social Sciences program (SPSS for Windows, release 7.5; SPSS Inc., Chicago, IL, USA). The $t$ test and one-way ANOVA test with Bonferroni correction, were used to test differences in mean dietary intake between groups. In order to assess the relative contributions of the demographic, social and lifestyle variables to the variation of the four dietary indicators, a twostep multiple regression model was applied. First education and location of residence were introduced together, with age forced into the model. Then each of the lifestyle variables, degree of attention paid to keeping a healthy diet, smoking habits and exercise, was introduced separately into the model together with age, education and residence.

\section{Results}

\section{Dietary intake according to sex and age}

The absolute daily intakes of energy and fibre were higher among men than women, but women had a higher intake of fruits and vegetables (Table 1). When computing intake per $10 \mathrm{MJ}$, women had $53 \%$ higher intake of fruits and vegetables, as compared with men. Furthermore, women had a higher intake of fibre, and a slightly lower percentage of dietary energy from fat than men. In both sexes the older age groups had a higher intake of fruits and vegetables and fibre per $10 \mathrm{MJ}$, as compared with the age groups 16-29 and 3039 years (Tables 2 and 3 ). Individuals aged 30-39 years had the highest fat E\%, and the age group 70-79 years had the highest Hegsted score, as compared with other age groups. This was seen among both men and women.

\section{Diet indicators related to social status and lifestyle}

Men and women with at least 13 years of education had higher intakes of fruits and vegetables and fibre, and lower fat $\mathrm{E} \%$ and Hegsted score, than those with less than 13 years of education (Tables 2 and 3 ). Both male and female whitecollar workers had higher intakes of fruits and vegetables and fibre than blue-collar workers. Female white-collar workers also had a lower fat E\% than female blue-collar workers. Income showed an inconsistent association with dietary factors among men and women. Men, as well as women, living in cities had a higher intake of fruits and vegetables than those living in rural areas. Males living in cities also had lower fat E\% and lower Hegsted score than

Table 1. Age and dietary characteristics of 1517 men and 1627 women selected as a representative random sample of the Norwegian population

(Mean values and standard deviations)

\begin{tabular}{|c|c|c|c|c|c|}
\hline & \multicolumn{2}{|c|}{ Men } & \multicolumn{2}{|c|}{ Women } & \multirow{2}{*}{$\begin{array}{c}\text { Statistical significance } \\
\text { of difference between } \\
\text { means, } P={ }^{*}\end{array}$} \\
\hline & Mean & SD & Mean & SD & \\
\hline Age (years) & $42 \cdot 9$ & $16 \cdot 3$ & $42 \cdot 0$ & $16 \cdot 9$ & 0.10 \\
\hline Energy $(\mathrm{MJ} / \mathrm{d})$ & $11 \cdot 7$ & 4.3 & 8.4 & 2.9 & $<0.001$ \\
\hline Fruits and vegetables $(\mathrm{g} / \mathrm{d})$ & 297 & 212 & 324 & 213 & $<0.001$ \\
\hline Fruits and vegetables ( $\mathrm{g} / 10 \mathrm{MJ})$ & 258 & 162 & 396 & 236 & $<0.001$ \\
\hline Fibre $(\mathrm{g} / \mathrm{d})$ & $26 \cdot 1$ & $10 \cdot 2$ & $20 \cdot 8$ & $8 \cdot 1$ & $<0.001$ \\
\hline Fibre (g/10 MJ) & $22 \cdot 7$ & $6 \cdot 2$ & 25.4 & $7 \cdot 0$ & $<0.001$ \\
\hline Fat (\% energy) & $30 \cdot 9$ & 5.9 & 29.9 & 5.9 & $<0.001$ \\
\hline Hegsted score $(\mathrm{mg} / \mathrm{dl}) \dagger$ & $28 \cdot 6$ & 7.6 & 28.9 & $7 \cdot 2$ & 0.27 \\
\hline
\end{tabular}

* Statistical analysis was by $t$ test.

† Determined by the equation: serum cholesterol $(\mathrm{mg} / \mathrm{dl})=2 \cdot 1$ saturated fatty acids $(\%$ energy) -1.16 polyunsaturated fatty 
Table 2. Dietary characteristics of a representative sample of Norwegian men subdivided by age and social factors (Mean values and standard deviations)

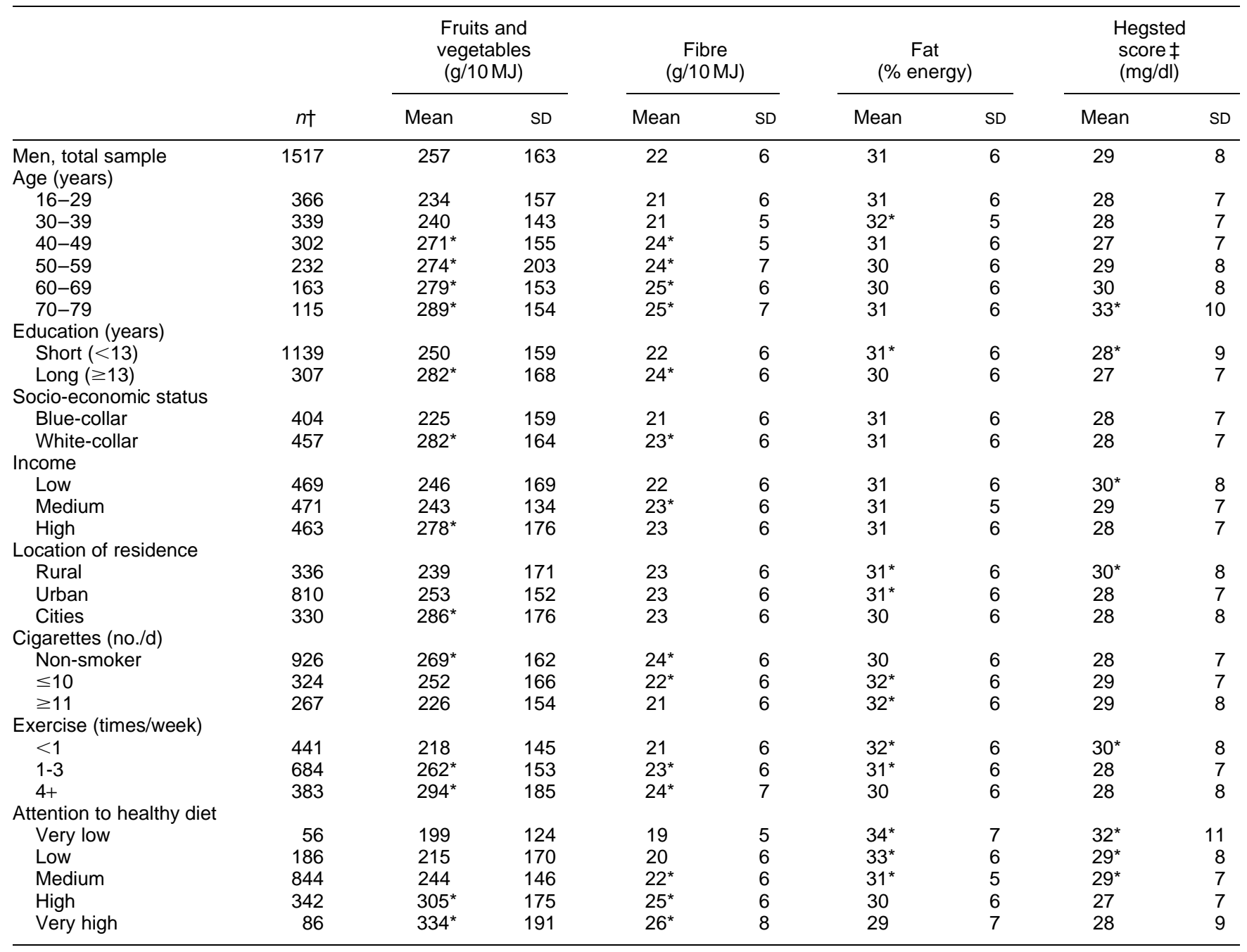

Mean values were significantly different from the lowest value (or two lowest values where identical) within the column: $P<0.05$ (one-way ANOVA with Bonferroni correction or $t$ test).

† Information about socio-demographic and lifestyle variables was missing for some subjects.

$\ddagger$ Determined by the equation: serum cholesterol $(\mathrm{mg} / \mathrm{dl})=2.1$ saturated fatty acids $(\%$ energy $)-1.16$ polyunsaturated fatty acids $(\%$ energy $)+0.067$ cholesterol $(\mathrm{mg} /$ $4184 \mathrm{~kJ})$.

males living in rural areas. Non-smokers had higher intakes of fruits and vegetables and fibre, as well as lower fat $\mathrm{E} \%$, compared with smokers. Subjects exercising regularly had higher intakes of fruits and vegetables and fibre, and lower fat $\mathrm{E} \%$ and Hegsted score than subjects exercising less than once weekly. Men and women paying high attention to a healthy diet had higher intakes of fruits and vegetables and fibre, as well as lower fat E\%, compared with those paying low or medium attention to a healthy diet. The magnitude of the difference in the level of dietary indicators was greatest between subjects paying different degrees of attention to keeping a healthy diet. Men and women paying high and very high attention to keeping a healthy diet had higher intakes of fruits and vegetables (47-85\%) and fibre $(32-33 \%)$, and lower fat E\% (14\%) and Hegsted score (10-11\%), compared with subjects paying low and very low attention to keeping a healthy diet.
Many of the socio-demographic and lifestyle variables were correlated. In both sexes the number of years in school was significantly higher among white-collar workers, subjects living in cities, non-smokers and subjects having regular exercise, as compared with subjects in other subgroups of socio-demographic and lifestyle variables. The number of years in school was also significantly higher among women who paid high and very high attention to a healthy diet, compared with those who paid very low to medium attention $(10.6 v$. 11.0 years; $P=0.008)$. This difference was not significant among men $(11 \cdot 1$ v. 11.4 years; $P=0 \cdot 058)$. Partial Pearson correlations controlled for age between length of education (5-20 years) and degree of attention paid to healthy diet (score $0-4)$ were $0 \cdot 10(P<0.001)$ among men and $0 \cdot 12(P<0 \cdot 001)$ among women. Among men with short and long education periods the percentages paying high and very high attention to a 
Table 3. Dietary characteristics of a representative sample of Norwegian women subdivided by age and social factors (Mean values and standard deviations)

\begin{tabular}{|c|c|c|c|c|c|c|c|c|c|}
\hline & $n \dagger$ & \multicolumn{2}{|c|}{$\begin{array}{c}\text { Fruits and } \\
\text { vegetables } \\
(\mathrm{g} / 10 \mathrm{MJ})\end{array}$} & \multicolumn{2}{|c|}{$\begin{array}{c}\text { Fibre } \\
(\mathrm{g} / 10 \mathrm{MJ})\end{array}$} & \multicolumn{2}{|c|}{$\begin{array}{c}\text { Fat } \\
\text { (\% energy) }\end{array}$} & \multicolumn{2}{|c|}{$\begin{array}{l}\text { Hegsted } \\
\text { score } \neq \\
\text { (mg/dl) }\end{array}$} \\
\hline $\begin{array}{l}\text { Women, total sample } \\
\text { Age (years) }\end{array}$ & 1627 & 395 & 235 & 25 & 7 & 30 & 6 & 29 & 7 \\
\hline $16-29$ & 479 & 347 & 214 & 23 & 6 & 30 & 6 & 27 & 6 \\
\hline $50-59$ & 214 & $461^{*}$ & 289 & $28^{*}$ & 8 & 30 & 6 & 29 & 8 \\
\hline $60-69$ & 174 & $457^{*}$ & 229 & $29^{*}$ & 6 & 28 & 6 & 30 & 9 \\
\hline $70-79$ & 131 & $445^{\star}$ & 242 & $27^{*}$ & 7 & 30 & 6 & $32^{*}$ & 8 \\
\hline \multicolumn{10}{|l|}{ Education (years) } \\
\hline Short $(<13)$ & 1224 & 381 & 229 & 25 & 7 & $30^{*}$ & 6 & $29^{*}$ & 7 \\
\hline Long ( $\geq 13)$ & 316 & $448^{*}$ & 253 & $27^{*}$ & 7 & 29 & 6 & 28 & 6 \\
\hline \multicolumn{10}{|l|}{ Socio-economic status } \\
\hline High & 471 & 395 & 224 & 25 & 7 & 31 & 6 & $29^{*}$ & 7 \\
\hline \multicolumn{10}{|l|}{ Location of residence } \\
\hline Rural & 328 & 369 & 208 & 25 & 7 & 30 & 6 & 30 & 7 \\
\hline Urban & 931 & 394 & 237 & 25 & 7 & 30 & 6 & 29 & 7 \\
\hline Cities & 321 & $427^{\star}$ & 251 & 26 & 7 & 29 & 6 & 28 & 8 \\
\hline \multicolumn{10}{|l|}{ Cigarettes (no./d) } \\
\hline Non-smoker & 1040 & $410^{*}$ & 224 & $26^{*}$ & 7 & 29 & 6 & 29 & 7 \\
\hline$\leq 10$ & 358 & 383 & 258 & 25 & 7 & $30^{*}$ & 6 & 29 & 7 \\
\hline$\geq 11$ & 229 & 353 & 247 & 24 & 7 & $31^{*}$ & 6 & 29 & 8 \\
\hline \multicolumn{10}{|l|}{ Exercise (times/week) } \\
\hline$<1$ & 367 & 344 & 231 & 23 & 6 & $31^{*}$ & 6 & $30^{*}$ & 7 \\
\hline $1-3$ & 818 & $397^{*}$ & 223 & $25^{*}$ & 7 & $30^{*}$ & 6 & 29 & 7 \\
\hline $4+$ & 429 & $435^{\star}$ & 254 & $27^{*}$ & 8 & 29 & 6 & 29 & 7 \\
\hline
\end{tabular}

Mean values were significantly different from the lowest value (or two lowest values where identical) within the column: $P<0.05$ (one-way ANOVA with Bonferroni correction or $t$ test).

† Information about socio-demographic and lifestyle variables was missing for some subjects.

$\ddagger$ Determined by the equation: serum cholesterol $(\mathrm{mg} / \mathrm{dl})=2.1$ saturated fatty acids $(\%$ energy $)-1.16$ polyunsaturated fatty acids $(\%$ energy $)+0.067$ cholesterol $(\mathrm{mg} /$ 4184 kJ).

healthy diet were $26 \%$ and $36 \%$ respectively, and among women $35 \%$ and $47 \%$ respectively.

The intake of fruits and vegetables was higher among subjects with long compared with short education periods in all subgroups of attention paid to healthy diet (Fig. 1 ( $a$ and $b)$ ). However, degree of attention to healthy diet had a larger impact on the intake of fruits and vegetables than education. For example, this intake was higher among both men and women with short education and high attention to keeping a healthy diet, as compared with those with long education and medium attention to keeping a healthy diet.

The largest difference in dietary indicators was found between young men with short education, living in rural areas, paying low attention to keeping a healthy diet, and middle-aged women with long education, living in cities, paying high attention to keeping a healthy diet. This subgroup of women aged 30-59 years had 300\% higher intake of fruits and vegetables $(132 v .581 \mathrm{~g} / 10 \mathrm{MJ})$ than the subgroup of men aged 16-29 years.

\section{Multiple regression analysis}

Age, education and location of residence together explained between 1 and $9 \%$ of the variation $\left(R^{2}\right)$ in the four dietary indicators, when introduced in the multiple regression model (Tables 4 and 5, step 1). In both sexes age was correlated to all four dietary indicators. Length of education was significantly associated with three of the four dietary indicators both among men and women. Residence in cities $v$. other areas was associated with higher intake of fruits and vegetables and lower intake of fat among men. Men living in rural areas had higher Hegsted score $v$. men living in other areas. 
When the variable 'attention paid to keeping a healthy diet' was included in the regression model (step 2), $R^{2}$ increased substantially for all four dietary indicators in both sexes. Age remained correlated to the dietary indicators, except for fat intake, in both sexes. Length of education remained significantly correlated with three dietary indicators
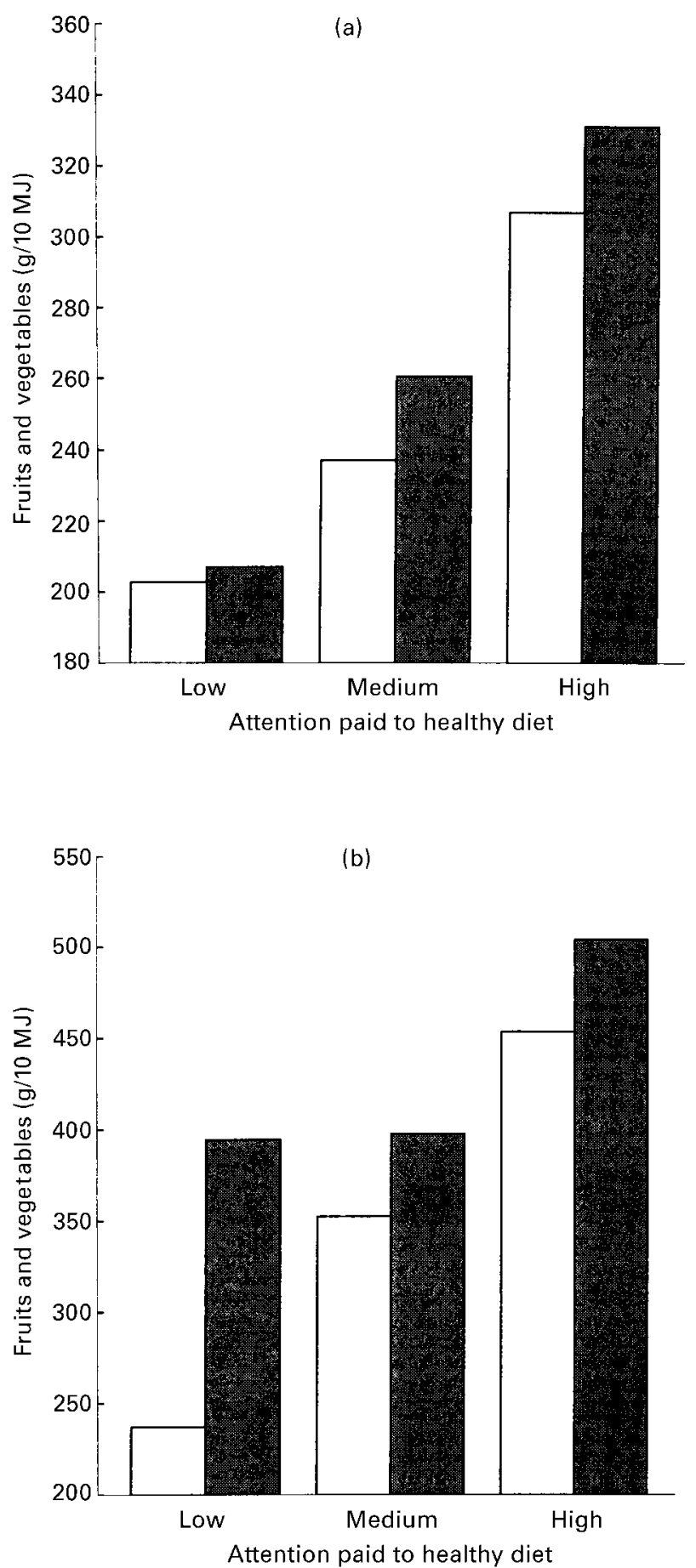

Fig. 1. Intake of fruits and vegetables $(\mathrm{g} / 10 \mathrm{MJ})$ in relation to degree of attention paid to eating a healthy diet and level of education ( $\square$ ), $<13$ years; (ם), 13+years) in (a) Norwegian men and (b) Norwegian women. among women and one among men. The correlations between residence and dietary indicators found in the first step remained significant among men, even after 'attention paid to keeping a healthy diet' was introduced in the model.

No significant interactions between length of education and degree of attention paid to keeping a healthy diet in relation to the variation of intake of the four dietary indicators were found. When we used education as a dichotomized variable ( $<13$ and $\geq 13$ years of education) in the regression models, this had minor effects on the results. As education and socio-economic status were strongly associated, only education was used as an indicator for social status in the regression model.

When frequency of leisure time physical exercise (1-4+ $v .<1$ times/week) was introduced instead of 'attention paid to keeping a healthy diet' in the regression model, regular exercise was significantly correlated to all four dietary indictors in both sexes, in a similar way as has been shown for degree of attention paid to keeping a healthy diet (results not shown). $R^{2}$ increased substantially when physical exercise was included in step 2 of the model, but not as much as when 'attention paid to keeping a healthy diet' was introduced. When degree of attention paid to keeping a healthy diet was replaced by smoking habits (smokers $v$. non-smokers) in the second step of the regression model, $R^{2}$ increased only slightly for most of the dietary indicators (results not shown). Non-smoking was positively correlated to intake of fibre, and negatively correlated to fat E\% among both men and women. Furthermore, non-smoking was also positively correlated with intake of fruits and vegetables and negatively correlated with Hegsted score among men.

\section{Discussion}

The present study, in common with several other studies, has shown that social status is correlated to indicators for healthy diet (Aarø, 1986; Prättälä et al. 1994). Thus, dietary differences may contribute to the lower mortality from chronic diseases observed among groups with high socioeconomic status in Norway (Jacobsen \& Thelle, 1988; Thürmer, 1993). However, social status was a weak predictor for healthy dietary habits in our survey, as well as in large surveys in the Netherlands, Australia and Finland (Hulshof et al. 1991; Smith \& Baghurst, 1992; Roos et al. 1996). Of the indicators for social status in our analysis, education was the best determinant of healthy dietary habits. The variable that showed the strongest and most consistent association with all four indicators of healthy dietary habits in both sexes was degree of attention paid to keeping a healthy diet. This indicates that personal preference may be a more important determinant of healthy dietary habits than social determinants such as education, socio-economic status and location of residence. However, one must bear in mind that education and attention to healthy diet were correlated. Furthermore, we had only one single variable indicating dietary attitudes in our survey.

The validity of the reported dietary habits depends on the survey method. The method used in our study has been evaluated against $14 \mathrm{~d}$ weighed records (Nes et al. 1992), $48 \mathrm{~h}$ recall (Solvoll et al. 1993) and against the concentration of 
Table 4. Multiple regression of indicators for dietary habits $v$. age, education, residence and attention to healthy diet in a representative sample of Norwegian men ( $n$ 1402)

$\left(\beta\right.$-Coefficients with $P$ values and adjusted $R^{2}$ )

\begin{tabular}{|c|c|c|c|c|c|c|c|c|}
\hline & \multicolumn{2}{|c|}{$\begin{array}{c}\text { Fruits and } \\
\text { vegetables } \\
(\mathrm{g} / 10 \mathrm{MJ})\end{array}$} & \multicolumn{2}{|c|}{$\begin{array}{c}\text { Fibre } \\
(\mathrm{g} / 10 \mathrm{MJ})\end{array}$} & \multicolumn{2}{|c|}{$\begin{array}{c}\text { Fat } \\
\text { (\% energy) }\end{array}$} & \multicolumn{2}{|c|}{$\begin{array}{l}\text { Hegsted } \\
\text { score } \\
(\mathrm{mg} / \mathrm{dl})\end{array}$} \\
\hline $\begin{array}{l}\text { Step } 1 \\
\quad \text { Age (16-79 years) } \\
\text { Education (5-20 years) } \\
\text { Residence (rural } v \text {. other) } \\
\text { Residence (cities } v \text {. other) }\end{array}$ & $\begin{array}{c}1 \cdot 4^{*} \\
4 \cdot 0^{\star} \\
-11 \cdot 0 \\
24 \cdot 8^{\star}\end{array}$ & $\begin{array}{r}<0.001 \\
0.018 \\
0.310 \\
0.022\end{array}$ & $\begin{array}{l}0.12^{*} \\
0.17^{\star} \\
0.32 \\
0.11\end{array}$ & $\begin{array}{r}<0.001 \\
0.010 \\
0.423 \\
0.795\end{array}$ & $\begin{array}{c}-0.03^{*} \\
-0.10 \\
0.28 \\
-1.1^{*}\end{array}$ & $\begin{array}{r}<0.001 \\
0.104 \\
0.483 \\
0.006\end{array}$ & $\begin{array}{c}0.06^{*} \\
-0.21^{*} \\
1.4^{*} \\
-0.22\end{array}$ & $\begin{array}{r}<0.001 \\
0.011 \\
0.005 \\
0.673\end{array}$ \\
\hline Adjusted $R^{2}(\%)$ & \multicolumn{2}{|c|}{2.5} & \multicolumn{2}{|c|}{8.5} & \multicolumn{2}{|c|}{1.4} & \multicolumn{2}{|c|}{$2 \cdot 9$} \\
\hline $\begin{array}{l}\text { Step } 2 \\
\quad \text { Age (16-79 years) } \\
\text { Education (5-20 years) } \\
\text { Residence (rural } v \text {. other) } \\
\text { Residence (cities } v \text {. other) } \\
\text { Attention to healthy diet }(0-4)\end{array}$ & $\begin{array}{l}0 \cdot 7^{*} \\
3 \cdot 0 \\
-4 \cdot 5 \\
22 \cdot 3^{*} \\
40 \cdot 3^{*}\end{array}$ & $\begin{array}{r}0.002 \\
0.073 \\
0.671 \\
0.036 \\
<0.001\end{array}$ & $\begin{array}{r}0.09^{*} \\
0.12 \\
0.64 \\
-0.02 \\
2.0^{*}\end{array}$ & $\begin{array}{r}<0.001 \\
0.065 \\
0.099 \\
0.962 \\
<0.001\end{array}$ & $\begin{array}{r}-0.02 \\
-0.06 \\
0.05 \\
-1.0^{\star} \\
-1.4^{\star}\end{array}$ & $\begin{array}{r}0.098 \\
0.289 \\
0.903 \\
0.010 \\
<0.001\end{array}$ & $\begin{array}{c}0 \cdot 08^{*} \\
-0 \cdot 17^{*} \\
1 \cdot 2^{*} \\
-0 \cdot 13 \\
1 \cdot 4^{*}\end{array}$ & $\begin{array}{r}<0.001 \\
0.033 \\
0.018 \\
0.797 \\
<0.001\end{array}$ \\
\hline
\end{tabular}

* Statistically significant at $P<0.05$.

very-long-chain $n$-3 fatty acids in plasma phospholipids (Frost Andersen et al. 1996). These studies showed that the questionnaire could be used for assessing intakes of a wide range of nutrients. Furthermore, results such as those reported in this paper may reflect systematic over-reporting of healthy habits among those paying particular attention to their diet. However, the fact that underreporting of energy intake did not differ systematically between subgroups with different degrees of attention paid to keeping a healthy diet can be taken as an indication of the validity of the findings (Johansson et al. 1998).
The external validity, i.e. the potential to generalize the observations, depends on the distribution of the responders with regard to social and demographic background. A skewed socio-demographic distribution of responders or a large drop-out of subjects with unhealthy dietary habits, may reduce the chance of revealing differences within the population. However, the present distribution of subjects with different socio-economic status, location of residence and length of education, was similar among the responders in our survey and the general population (Statistics Norway, 1995), and there were only small differences between

Table 5. Multiple regression of indicators for dietary habits $v$. age, education, residence and attention to healthy diet in a representative sample of Norwegian women ( $n$ 1492)

( $\beta$-Coefficients with $P$ values and adjusted $R^{2}$ )

\begin{tabular}{|c|c|c|c|c|c|c|c|c|}
\hline & \multicolumn{2}{|c|}{$\begin{array}{c}\text { Fruits and } \\
\text { vegetables } \\
(\mathrm{g} / 10 \mathrm{MJ})\end{array}$} & \multicolumn{2}{|c|}{$\begin{array}{c}\text { Fibre } \\
\text { (g/10 MJ) }\end{array}$} & \multicolumn{2}{|c|}{$\begin{array}{c}\text { Fat } \\
\text { (\% energy) }\end{array}$} & \multicolumn{2}{|c|}{$\begin{array}{l}\text { Hegsted } \\
\text { score } \\
(\mathrm{mg} / \mathrm{dl})\end{array}$} \\
\hline & $\beta$ & $P$ & $\beta$ & $P$ & $\beta$ & $P$ & $\beta$ & $P$ \\
\hline $\begin{array}{l}\text { Step } 1 \\
\text { Age (16-79 years) } \\
\text { Education (5-20 years) } \\
\text { Residence (rural } v \text {. other) } \\
\text { Residence (cities } v \text {. other) }\end{array}$ & $\begin{array}{c}3 \cdot 1^{*} \\
12 \cdot 9^{*} \\
-18 \cdot 8 \\
29 \cdot 4\end{array}$ & $\begin{array}{r}<0.001 \\
<0.001 \\
0.213 \\
0.056\end{array}$ & $\begin{array}{l}0.13^{*} \\
0.43^{*} \\
0.02 \\
0.23\end{array}$ & $\begin{array}{r}<0.001 \\
<0.001 \\
0.956 \\
0.614\end{array}$ & $\begin{array}{l}-0.02^{*} \\
-0.24^{*} \\
-0.17 \\
-0.76\end{array}$ & $\begin{array}{r}0.010 \\
<0.001 \\
0.665 \\
0.056\end{array}$ & $\begin{array}{r}0.06^{*} \\
-0.14 \\
0.14 \\
-0.58\end{array}$ & $\begin{array}{r}<0.001 \\
0.079 \\
0.759 \\
0.219\end{array}$ \\
\hline Adjusted $R^{2}(\%)$ & \multicolumn{2}{|c|}{5.5} & \multicolumn{2}{|c|}{9.4} & \multicolumn{2}{|c|}{$1 \cdot 1$} & \multicolumn{2}{|c|}{$2 \cdot 4$} \\
\hline $\begin{array}{l}\text { Step } 2 \\
\quad \text { Age (16-79 years) } \\
\text { Education ( } 5-20 \text { years) } \\
\text { Residence (rural } v \text {. other) } \\
\text { Residence (cities } v \text {. other) } \\
\text { Attention to healthy diet }(0-4)\end{array}$ & $\begin{array}{r}2 \cdot 2^{*} \\
10 \cdot 2^{*} \\
-17 \cdot 7 \\
25 \cdot 1 \\
73 \cdot 4^{*}\end{array}$ & $\begin{array}{r}<0.001 \\
<0.001 \\
0.228 \\
0.094 \\
<0.001\end{array}$ & $\begin{array}{l}0.10^{*} \\
0.34^{*} \\
0.06 \\
0.09 \\
2 \cdot 3^{*}\end{array}$ & $\begin{array}{r}<0.001 \\
<0.001 \\
0.890 \\
0.840 \\
<0.001\end{array}$ & $\begin{array}{l}-0.005 \\
-0.18^{*} \\
-0.19 \\
-0.66 \\
-1.60^{\star}\end{array}$ & $\begin{array}{r}0.606 \\
0.007 \\
0.615 \\
0.088 \\
<0.001\end{array}$ & $\begin{array}{r}0.07^{*} \\
-0.10 \\
0.12 \\
-0.50 \\
-1.2^{*}\end{array}$ & $\begin{array}{r}<0.001 \\
0.229 \\
0.788 \\
0.280 \\
<0.001\end{array}$ \\
\hline Adjusted $R^{2}(\%)$ & \multicolumn{2}{|c|}{$10 \cdot 3$} & \multicolumn{2}{|c|}{$15 \cdot 0$} & \multicolumn{2}{|c|}{$4 \cdot 7$} & \multicolumn{2}{|c|}{$3 \cdot 8$} \\
\hline
\end{tabular}

* Statistically significant at $P<0.05$. 
responders and the total sample regarding age, sex, geographical distribution and educational level (Johansson et al. 1997a). Other surveys indicate that health-conscious subjects are more willing to participate in dietary surveys (Jörgensen, 1992; Osler \& Scroll, 1992), and that selective drop out may lead to underestimation of the real differences related to social status in the population (Turrel \& Najman, 1995). However, we have no way of assessing whether our responders had healthier habits than non-responders.

In the present survey age was associated with all four indicators for healthy diet in both sexes. Women reported a healthier diet than men. Dietary differences between Norwegian men and women have previously been reported in dietary surveys among selected groups (Blaker et al. 1988) and in surveys using food-frequency or qualitative questionnaires in large samples (Solvoll et al. 1989; Wandel, 1995), as well as in surveys in other industrialized countries (Subar et al. 1992; Kleemola et al. 1994). Nonsmokers of both sexes reported a higher intake of fibre, and lower fat $\mathrm{E} \%$ than smokers. A less healthy diet among smokers compared with non-smokers has also been reported in other studies (Margetts \& Jackson, 1993; Jarvinen et al. 1994; Trygg et al. 1995).

The Norwegian diet has become lower in fat, the fatty acid pattern has improved and the consumption of fruits and vegetables has increased during the last 20 years (National Nutrition Council, 1996). When compared with previously performed dietary surveys (Johansson et al. 1996) the present survey indicated that all groups of the population have changed towards a lower-fat diet. However, dietary differences related to sex, social status and location of residence still exist. This pattern fits with the hypothesis that dietary changes diffuse from high social status groups and urban areas to other parts of society (Rogers, 1995). Thus, we may expect a delay between groups of different social status regarding healthy food choices. For example, traditionally the Norwegian diet was lower in fat in rural areas as compared with cities, but during the last 20 years the dietary lipid pattern (Johansson et al. 1996), as well as the mortality from CHD have improved more in urban than in rural areas (Westlund, 1971; Krüger et al. 1995). In our present study, men living in rural districts had higher Hegsted scores and lower intakes of fruits and vegetables, than men living in cities. Furthermore, the Hegsted score was on average $5 \mathrm{mg} / \mathrm{dl}$ lower in the youngest compared with the oldest age group, corresponding to a $2 \%$ difference in serum cholesterol (Bjartveit et al. 1991) and a 6-10\% difference in the risk of CHD (Law et al. 1994). It is difficult to tell what has caused the observed dietary changes, but they coincide with two decades of follow-up of the Norwegian Food and Nutrition Policy (Ministry of Health and Social Affairs, 1992). The present analysis suggests that dietary habits are associated with social status, but also that personal preferences may be very important independent of social status. This may have been promoted by systematic nutrition education.

In conclusion, we found that healthy diet was associated with social status and other lifestyle habits. As the official health promotion policy aims at improving health for everybody and decreasing health differences within the population, it is important to strengthen nutrition education in the general population and in particular among low social status groups with high incidence of non-infectious chronic diseases.

\section{Acknowledgements}

The project was carried out in cooperation with the Norwegian Food Control Authority and with grant support from the Ministry for Agriculture, the Ministry for Health and Social Affairs and the Norwegian Research Council. The contributions of Christina Bergsten, Bodil Blaker, Elin B. Løken, Randi Selmer and Gunnar Åmlid are highly appreciated.

\section{References}

Aarø LE (1986) Health behaviour and socio-economic status. A survey among the adult population in Norway. $\mathrm{PhD}$ Thesis, University of Bergen, Norway.

Axelson ML (1986) The impact of culture on food-related behavior. Annual Review of Nutrition 6, 345-363.

Bjartveit K, Stensvold I, Lund-Larsen PG, Gjervig T, Krüger $\varnothing$ \& Urdal P (1991) Cardiovascular diseases prevention programmes in Norwegian counties (English summary). Tidskrift for Den Norske Laegeforening 111, 2063-2072.

Blaker B \& Aarsland M (1989) Household Measures and Weights of Foods (in Norwegian). Otta: Engers Boktrykkeri A/S.

Blaker B, Solvoll K \& Lund-Larsen K (1988) Dietary Habits in Vestre Toten 1987. Results From a $24 \mathrm{~h}$ Recall in Men and Women 30-59 Years of Age (in Norwegian). Oslo: Section for Dietary Research, University of Oslo.

Blaxter M (1987) Evidence on inequality in health from a national survey. Lancet 2, 30-33.

Blaxter M (1990) Health and Lifestyles. London: Tavistock/Routledge.

Central Bureau of Statistics (1977) Sampling Methods Applied by the Central Bureau of Statistics of Norway. Samfunns $\phi$ konomiske Studier no. 33. Oslo: Central Bureau of Statistics.

Central Bureau of Statistics (1984) Standard Classification of Socio-economic Status. Standards for Norwegian Statistics no. 5. Oslo: Kongsvinger.

Central Bureau of Statistics (1989) Standard Classification of Education, revised 1989. Oslo: Kongsvinger.

Department of Health and Human Services (1988) The Surgeon General's Report on Nutrition and Health. US (PHS) Publication no. 88-50210. Washington, DC: Public Health Service.

Frost Andersen L, Solvoll K \& Drevon CA (1996) Very long-chain $n-3$ fatty acids as biomarkers for intake of fish and $n-3$ fatty acid concentrates. American Journal of Clinical Nutrition 64, 305311.

Gregory J, Foster K, Tyler H \& Wiseman M (1990) The Dietary and Nutritional Survey of British Adults. London: H. M. Stationery Office.

Hegsted M, Ausman LM, Johnson JA \& Dallal GE (1993) Dietary fat and serum lipids: an evaluation of the experimental data. American Journal of Clinical Nutrition 57, 875-883.

Hollis JF, Carmody TP, Connor SL, Fey SG \& Matarazzo JD (1986) The Nutrition Attitude Survey: associations with dietary habits, psychological and physical well-being, and coronary risk factors. Health Psychology 5, 359-374.

Holme I, Helgeland A, Hjermann I, Leren P \& Lund-Larsen PG (1980) Four-year mortality by some socio-economic indicators. The Oslo study. Journal of Epidemiology and Community Health 34, 48-52.

Hulshof KF, Löwik MR, Kok FJ, Wedel M, Brants HA, Hermus RJ $\&$ ten Hoor F (1991) Diet and other life-style factors in high and 
low socio-economic groups (Dutch Nutrition Surveillance System). European Journal of Clinical Nutrition 45, 441-450.

Hulshof KF, Wedel M, Löwik MR, Kok FJ, Kistemaker C, Hermus RJ, ten Hoor F \& Ockhuizen T (1992) Clustering of dietary variables and other lifestyle factors (Dutch Nutritional Surveillance System). Journal of Epidemiology and Community Health 46, 417-424.

Jacobsen BJ \& Thelle DS (1988) The Troms $\varnothing$ Heart Study: risk factors for coronary heart disease and length of education. American Journal of Epidemiology 127, 923-932.

Jarvinen R, Knekt P, Seppänen R, Reunanen A, Heliovaara M, Maatela J \& Aromaa A (1994) Antioxidant vitamins in the diet: relationships with other personal characteristics in Finland. Journal of Epidemiology and Community Health 48, 549-554.

Johansson L, Drevon CA \& Bjørneboe GE Aa (1996) The Norwegian diet during the last hundred years in relation to coronary heart disease. European Journal of Clinical Nutrition 50, 277-283.

Johansson L, Solvoll K, Bjørneboe G-E Aa \& Drevon CA (1997a) Dietary habits among Norwegian men and women. Scandinavian Journal of Nutrition 41, 63-70.

Johansson L, Solvoll K, Bjørneboe G-E Aa \& Drevon CA (1998) Under- and overreporting of energy intake related to weight status and lifestyle in a nationwide sample. American Journal of Clinical Nutrition 68, 266-274.

Johansson L, Solvoll K, Opdahl S, Bjørneboe G-E Aa \& Drevon CA (1997b) Response rates with different distribution methods and reward, and reproducibility of a quantitative food-frequency questionnaire. European Journal of Clinical Nutrition 51, 346353.

Jörgensen LM (1992) Who completes seven-day food records? European Journal of Clinical Nutrition 46, 735-741.

Kaplan GA \& Keil JE (1993) Socioeconomic factors and cardiovascular disease: a review of the literature. Circulation 88, 1973-1998.

Kleemola P, Virtanen M \& Pietinen P (1994) The 1992 Dietary Survey of Finnish Adults. Publications of the National Public Health Institute, B2/1994. Helsinki: National Public Health Institute.

Kristofersen LB (1986) Mortality Among Occupationally Active. Social Differences During the 1970s (in Norwegian). Oslo: Central Bureau of Statistics.

Krüger O, Aase A \& Westin S (1995) Ischaemic heart disease mortality among men in Norway: reversal of urban-rural difference between 1966 and 1989. Journal of Epidemiology and Community Health 49, 271-276.

Law MR, Wald NJ \& Thompson SG (1994) By how much and how quickly does reduction in serum cholesterol concentration lower risk of ischaemic heart disease? British Medical Journal 308, 367-372.

Liberatos P, Link BG \& Kelsey JL (1988) The measurement of social class in epidemiology. Epidemiology Review 10, 87-121.

Luoto R, Pekkanen J, Uutela A \& Tuomilehto J (1994) Cardiovascular risks and socioeconomic status: differences between men and women in Finland. Journal of Epidemiology and Community Health 48, 348-354.

Lynch JW, Kaplan GA, Cohen RD, Tuomilehto J \& Salonen JT (1996) Do cardiovascular risk factors explain the relation between socioeconomic status, risk of all-cause mortality, cardiovascular mortality, and acute myocardial infarction? American Journal of Epidemiology 144, 934-942.

Lynch JW, Kaplan GA \& Salonen JT (1997) Why do poor people behave poorly? Variation in adult health behaviours and psychosocial characteristics by stages of the socioeconomic lifecourse. Social Science and Medicine 44, 809-819.

Mackenbach JP, Kunst AE, Cavelaars AE, Groenhof F \& Geurts JJ (1997) Socioeconomic inequalities in morbidity and mortality in western Europe. The EU Working Group on Socioeconomic Inequalities in Health. Lancet 349, 1655-1659.

Mæland JG \& Aarø LE (1993) The theoretical basis for health education in medical practice. Tidskrift for Den Norske Lageforening 113, 51-55.

Margetts BM \& Jackson AA (1993) Interactions between people's diet and their smoking habits: the dietary and nutritional survey of British adults. British Medical Journal 307, 1381-1384.

Marmot MG, Smith GD \& Stansfeld S (1991) Health inequalities among British civil servants: the Whitehall study. Lancet 337, $1387-1392$.

Ministry of Health and Social Affairs (1992) Report No. 37 to the Storting (1992-93). Challenges in Health Promotion and Prevention Strategies. Oslo: Ministry of Health and Social Affairs.

National Nutrition Council (1996) Trends in Norwegian Dietary Habits (in Norwegian). Oslo: National Nutrition Council.

Nes M, Frost Andersen L, Solvoll K, Sandstad B, Hustvedt BE, Løvø A \& Drevon CA (1992) Accuracy of a quantitative foodfrequency questionnaire applied in elderly Norwegian women. European Journal of Clinical Nutrition 42, 809-821.

Osler M \& Schroll M (1992) Differences between participants and non-participants in a population study on nutrition and health in the elderly. European Journal of Clinical Nutrition 46, 289295.

Pietinen P, Uusitalo U, Vartiainen E \& Tuomilehto J (1988) Dietary survey of the FINMONICA project in 1982. Acta Medica Scandinavica 28, Suppl. 7, 169-177.

Prättälä R, Karisto A \& Berg M-A (1994) Consistency and variation in unhealthy behaviour among Finnish men, 19821990. Social Science and Medicine 39, 115-122.

Rogers EM (1995) Lessons for guidelines from the diffusion of innovations. Joint Commission Journal on Quality Improvement 7, 324-328.

Roos E, Prättälä R, Lahelma E, Kleemola P \& Pietinen P (1996) Modern and healthy?: socioeconomic differences in the quality of diet. European Journal of Clinical Nutrition 50, 753-760.

Smith AM \& Baghurst KI (1992) Public health implications of dietary differences between social status and occupational category groups. Journal of Epidemiology and Community Health 46, 409-416.

Smith AM \& Owen N (1992) Associations of social status and health-related beliefs with dietary fat and fiber densities. Preventive Medicine 21, 735-745.

Solvoll K, Lund-Larsen K, Søyland E, Sandstad B \& Drevon CA (1993) A quantitative food-frequency questionnaire evaluated in a group of dermatologic outpatients. Scandinavian Journal of Nutrition 37, 150-155.

Solvoll K, Selmer R, Løken EB, Foss OP \& Trygg K (1989) Coffee, dietary habits, and serum cholesterol among men and women 35-49 years of age. American Journal of Epidemiology 129, 1277-1288.

Statistics Norway (1993) Omnibus Survey. Technical Report June, September and November 1993, March 1994 (in Norwegian). Oslo: Statistics Norway.

Statistics Norway (1994) Standard Classification of Municipalities. Official Statistics of Norway, C 192. Oslo: Kongsvinger.

Statistics Norway (1995) Statistical Yearbook 1995. Official Statistics of Norway, C 247. Oslo: Kongsvinger.

Subar AS, Heimendinger J, Krebs-Smith SM, Patterson B, Kessler $\mathrm{R} \&$ Pivonka E (1992) 5-A-DAY for Better Health: A Baseline Study of American's Fruit and Vegetable Consumption. Bethesda, MD: National Cancer Institute.

Trygg K, Lund-Larsen K, Sandstad B, Hoffman HJ, Jacobsen G \& Bakketeig LS (1995) Do pregnant smokers eat differently from pregnant non-smokers? Paediatric and Perinatal Epidemiology 9, 307-319.

Thürmer H (1993) Risk factors for, and 13-year mortality from, 
cardiovascular disease by socioeconomic status. Thesis, National Health Screening Service, Oslo and Institute of Community Medicine, University of Troms $\varnothing$, Norway.

Turrell G \& Najman JM (1995) Collecting food-related data from low socioeconomic groups: how adequate are our current research designs? Australian Journal of Public Health 19, 410-416.

Wandel M (1995) Dietary intake of fruit and vegetables in Norway: influence of life phase and socio-economic factors. International Journal of Food Sciences and Nutrition 46, 291301.

Westlund K (1971) The variation in incidence of coronary infarction (Norwegian). Nordisk Medicin 85, 458-474.

Winkleby MA, Jatulis DE, Frank E \& Fortmann SP (1992)
Socioeconomic status and health: how education, income, and occupation contribute to risk factors for cardiovascular disease. American Journal of Public Health 82, 816-820.

Witte DJ, Skinner JD \& Carruth BR (1991) Relationship of selfconcept to nutrient intake and eating patterns in young women. Journal of the American Dietetic Association 9, 1068-1073.

World Cancer Research Fund/American Institute for Cancer Research (1997) Food, Nutrition and the Prevention of Cancer: A Global Perspective. Washington, DC: World Cancer Research Fund and American Institute for Cancer Research.

World Health Organization (1990) Diet, Nutrition, and the Prevention of Chronic Diseases. Report of a WHO Study Group. Technical Report Series no. 797. Geneva: WHO. 